\title{
Autoregressive Integrated Moving Average (Arima) Dalam Memprediksi Jumlah Penjualan Frame
}

\author{
Article Info \\ Article history: \\ Received 26 February 2020 \\ Revised 27 March 2020 \\ Accepted 01 April 2020 \\ Keywords: \\ Ektaco Photo Source Prediction \\ Arima Method
}

\begin{abstract}
Ektaco Sumber Foto is a company engaged in photo printing and is one of the largest photo labs in, which serves and facilitates photography needs for photographers. Ektaco Sumber Foto serves every day and facilitates the needs of photographers such as photo printing, frames, exclusive albums and press albums. The world of photographers is experiencing very rapid development from the film era to the digital era, which makes consumers changing modernize photographer prints with certain and sizes and combine them with photo frames. Forecasting is forecasting something that hasn't happened yet. This research was conducted with quantitative forecasting methods. The Box-Jenkins Periodic Series (ARIMA) method is a forecasting method that involves statistical analysis of past data. This ARIMA completely ignores the independent variables because this model uses the present values and past values of the independent variables to produce accurate short-term predictions or forecasts. Forecasting is important for every business organization and for every management decision making that is very significant. Forecasting is the basis for a company's long-term planning. The accuracy of the results of business forecasting will increase opportunities for achieving profitable investments in the company.
\end{abstract}

This is an open access article under the CC BY-SA license.

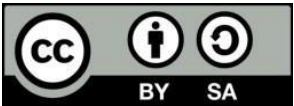

Corresponding Author:

Pristiwanto

STMIK Budi Darma Medan, Technical Information, Medan, Indonesia

Email Address: 4nt0.82@gmail.com

\section{Pendahuluan}

Ektaco Sumber Foto adalah perusahaan yang bergerak di bidang percetakan foto dan merupakan salah satu lab foto terbesar yang melayani dan memfasilitasi kebutuhan fotografi para fotografer. Ektaco Sumber Foto melayani dan memfasilitasi kebutuhan fotografer setiap hari, seperti pencetakan foto, bingkai, album eksklusif, dan album pers. Fotografer berkembang sangat pesat dari era film hingga era digital, yang membuat konsumen semakin memodernisasi hasil cetakan fotografer dengan desain dan ukuran tertentu serta memadukannya dengan bingkai foto. Bingkai adalah tepi dekoratif yang dibuat untuk menempelkan gambar, foto, atau lukisan [1], [2]. Bentuk kusen biasanya persegi panjang atau lonjong, atau dengan bentuk lain dengan berbagai motif dan warna. Bingkai foto biasanya digantung di dinding atau dipajang di atas meja. Ektaco Sumber Foto menyediakan frame 
berbahan fiber, yang memiliki banyak motif dan beberapa warna yang bisa dipesan sesuai ukuran yang diinginkan oleh fotografer. Banyaknya motif dan warna bingkai foto yang tersedia membuat Ektaco Sumber Foto masih kesulitan menyediakan bingkai foto. Prediksi penjualan yang buruk mengakibatkan penimbunan barang yang berlebihan bahkan kekurangan barang secara tepat waktu lebih cepat dari perkiraan waktu sebelumnya. Stockpile dan kekurangan stockpile bingkai foto sangat berpengaruh terhadap penjualan di Ektaco Sumber Foto, karena setiap fotografer selalu Prediksi penjualan yang buruk mengakibatkan penimbunan barang yang berlebihan bahkan kekurangan barang secara tepat waktu lebih cepat dari perkiraan waktu sebelumnya. Stockpile dan kekurangan stockpile bingkai foto sangat berpengaruh terhadap penjualan di Ektaco Sumber Foto, karena setiap fotografer selalu Prediksi penjualan yang buruk mengakibatkan penimbunan barang yang berlebihan bahkan kekurangan barang secara tepat waktu lebih cepat dari perkiraan waktu sebelumnya. Stockpile dan kekurangan stockpile bingkai foto sangat berpengaruh terhadap penjualan di Ektaco Sumber Foto, karena setiap fotografer selalu

menyesuaikan bingkai foto dengan permintaan foto dari fotografer. Prediksi atau peramalan sangat berguna untuk melihat gambaran masa depan agar Kepala Ektaco Sumber Foto dapat mengantisipasinya dengan kejadian yang akan datang, sehingga tidak terjadi penumpukan atau kekosongan stok bingkai foto. Misalnya, Ektaco Sumber Foto dapat memperkirakan motif dan warna bingkai apa yang diminati di tahun 2016. Fotografer dapat terus menyesuaikan foto hasil cetakannya dengan bingkai foto yang sesuai. Prediksi atau ramalan yang baik akan meningkatkan penjualan di Ektaco Sumber Foto, karena fotografer tidak akan kecewa karena stok bingkai yang diminati akan tetap terpenuhi dan motif bingkai foto akan terus diperbarui sesuai dengan waktu yang diprediksi [3], [4] dengan melihat jumlah penjualan pada tahun-tahun sebelumnya. Stockpile dan kekurangan stockpile bingkai foto sangat berpengaruh terhadap penjualan di Ektaco Sumber Foto, karena setiap fotografer selalu menyesuaikan bingkai foto dengan permintaan foto dari fotografer. Prediksi atau peramalan sangat berguna untuk melihat gambaran masa depan agar Kepala Ektaco Sumber Foto dapat mengantisipasinya dengan kejadian yang akan datang, sehingga tidak terjadi penumpukan atau kekosongan stok bingkai foto. Misalnya, Ektaco Sumber Foto dapat memperkirakan motif dan warna bingkai apa yang diminati di tahun 2016. Fotografer dapat terus menyesuaikan foto hasil cetakannya dengan bingkai foto yang sesuai. Prediksi atau ramalan yang baik akan meningkatkan penjualan di Ektaco Sumber Foto, karena fotografer tidak akan kecewa karena stok frame yang diminati akan tetap terpenuhi dan motif frame foto akan terus di update sesuai prediksi waktu [3], [4] dengan melihat jumlah penjualan pada tahun-tahun sebelumnya. Uraian permasalahan yang dilihat dan mengetahui keuntungan yang dihasilkan dari penjualan [5], [6] bingkai foto di Ektaco Sumber Foto, maka Ektaco Sumber Foto menggunakan peramalan dengan metode ARIMA untuk mengetahui penjualan bingkai foto di tahun-tahun mendatang. Peramalan adalah perkiraan tentang sesuatu yang belum terjadi. kemudian Ektaco Sumber Foto menggunakan peramalan dengan metode ARIMA untuk mengetahui penjualan bingkai foto di tahun-tahun mendatang. Peramalan adalah perkiraan tentang sesuatu yang belum terjadi kemudian Ektaco Sumber Foto menggunakan peramalan dengan metode ARIMA [7] untuk mengetahui penjualan bingkai foto di tahun-tahun mendatang. Peramalan adalah perkiraan tentang sesuatu yang belum terjadi [9].

\section{Metode}

Dalam pembahasan ini diperlukan suatu masalah dalam tahapan penelitian dan lebih banyak lagi data yang akan dijadikan dasar pemecahan masalah yang sedang dihadapi. 
1. Pengumpulan data

Data dalam penelitian diperoleh langsung dari objek penelitian dan dari berbagai

sumber. Lakah-langkah dalam pengumpulan data dijelaskan sebagai berikut. Sebuah. Pengamatan

a. Observasi dalam penelitian ini dilakukan oleh peneliti dan observer. Observasi dalam penelitian ini adalah observasi langsung yaitu melihat dan mengamati secara langsung, kemudian merekam tingkah laku dan peristiwa yang terjadi pada kondisi yang sebenarnya.

b. Wawancara

Wawancara dalam penelitian ini menggunakan wawancara tidak terstruktur karena peneliti menganggap model ini paling fleksibel, dimana subjek diberi kebebasan untuk mendeskripsikan jawaban dan mengungkapkan pandangannya secara bebas dan sesuai hari.

c. Tinjauan Literatur

d. Metode pengumpulan datanya adalah dengan studi literatur yaitu dengan memahami masalah dan mengumpulkan data dari artikel, karya ilmiah, buku, dokumen dan cetakan serta file yang bersumber dari internet sehingga penelitian

2. Analisis data ini dapat dipercaya.

Setelah semua data terkumpul, selanjutnya dilakukan analisis data melalui beberapa tahapan. Mengumpulkan data penjualan bingkai foto dari beberapa tahun sebelumnya untuk menghitung penjualan di masa mendatang. Kemudian klarifikasi data, dan tabulasi data yang tẹlah dikumpulkan. Selanjutnya, pengolahan data dilakukan dalam bentuk komputerisasi.

a. Penerapan Metode

Ketika data telah disiapkan dengan jelas, langkah selanjutnya adalah menggunakan metode Arima sebagai bagian dari Sistem Pendukung Keputusan dan menghasilkan nilai secara manual.

b. Desain Aplikasi

Proses perancangan aplikasi disesuaikan dengan alur kerja sistem, tahapan kerja sistem dan tahapan sistem berjalan dengan baik. Pada tahap desain, peneliti mendeskripsikan kerangka sistem melalui flowchart, desain proses melalui DFD (Data flow diagram), desain database, dan desain antarmuka.

c. Pengujian Aplikasi

Tahapan ini merupakan pengujian terhadap sistem yang telah dibuat dengan menggunakan pengujian black box.Pengujian black box dilakukan dalam bentuk pengujian faktor kebenaran berupa:

kebutuhan fungsional sistem dan pengujian aliran dan hasil perhitungan sistem, untuk memastikan bahwa perhitungan yang dilakukan oleh sistem sesuai dengan aliran yang benar [10], [11].

\section{Hasil dan Pembahasan}

Ektaco Sumber Foto adalah salah satu lab foto terbesar di kota ini yang bergerak di bidang percetakan foto dan penyedia kebutuhan cetak foto, album press, album eksklusif dan bingkai foto. Peningkatan jumlah penjualan per tahun selalu menjadi hal penting yang sangat diharapkan oleh Ektaco Sumber Foto,

oleh karena itu perlu untuk memprediksi atau meramalkan gambaran masa depan masalah penjualan frame di Ektaco Sumber Foto. Ektaco Sumber Foto sangat berharap akan terjadi peningkatan penjualan bingkai foto setiap tahunnya, maka untuk membantu meningkatkan penjualan bingkai foto, Ektaco Sumber Foto menerapkan metode peramalan ke depan dengan melihat data penjualan tahun sebelumnya[12].

\section{Data Jumlah Bingkai Foto}

Data yang akan dianalisis dalam penelitian ini adalah data jumlah penjualan bingkai foto di Ektaco Sumber Foto. Seperti pada rumusan masalah, data yang dianalisis adalah data jumlah penjualan bingkai foto dari tahun 2016 sampai dengan tahun 2019, yang 


\section{Pristiwanto}

doi.org/10.54209/jatilima.v2i1.142

diperoleh dari Ektaco Sumber Foto seperti terlihat pada tabel di bawah ini:

Tabel 1. Data Penjualan Bingkai Foto di Ektaco Photo Source

\begin{tabular}{|l|l|l|l|l|}
\hline \multirow{2}{*}{$\begin{array}{l}\text { Kode } \\
\text { Bingkai }\end{array}$} & \multicolumn{4}{|c|}{ Tahun } \\
\cline { 2 - 5 } E10048 & 2016 & 2017 & 2018 & 2019 \\
\hline E55060111W & 185 & 148 & 126 & 216 \\
\hline E1022ABS & 173 & 234 & 275 & 324 \\
\hline E808081C & 240 & 164 & 141 & 206 \\
\hline E1867WS & 184 & 213 & 250 & 163 \\
\hline E104070W & 159 & 226 & 241 & 439 \\
\hline E8054010G & 111 & 118 & 145 & 120 \\
\hline E5511011H & 87 & 101 & 97 & 121 \\
\hline E6015056 & 110 & 176 & 195 & 294 \\
\hline E878A20 & 162 & 120 & 284 & 323 \\
\hline E878A1842 & 99 & 127 & 140 & 154 \\
\hline E3214 & 137 & 193 & 285 & 346 \\
\hline E41411S & 138 & 136 & 140 & 209 \\
\hline E96007478 & 172 & 274 & 388 & 418 \\
\hline E9670083093 & 125 & 241 & 346 & 382 \\
\hline E324040S & 120 & 141 & 190 & 203 \\
\hline E5505011 & 92 & 166 & 202 & 183 \\
\hline E821858 & 91 & 162 & 306 & 270 \\
\hline E8522105 & 151 & 216 & 264 & 349 \\
\hline E8006303 & 190 & 246 & 283 & 362 \\
\hline E243980I & 180 & 245 & 327 & 390 \\
\hline E243980Y & 148 & 323 & 351 & 403 \\
\hline
\end{tabular}

Nilai koefisien autokorelasi dan autokorelasi parsial dari data jumlah bingkai foto dapat diperoleh sebagai berikut:

Tabel 2. Nilai Koefisien Autokorelasi dan Autokorelasi Parsial

\begin{tabular}{|l|l|l|l|}
\hline ketinggalan & Autokorelasi & ketinggalan & Autokorelasi Parsial \\
\hline 1 &, 159 & 1 &, 159 \\
\hline 2 &,- 499 & 2 &,- 538 \\
\hline
\end{tabular}

Plot nilai koefisien autokorelasi dan autokorelasi parsial dari data asli dapat dilihat pada gambar berikut: 


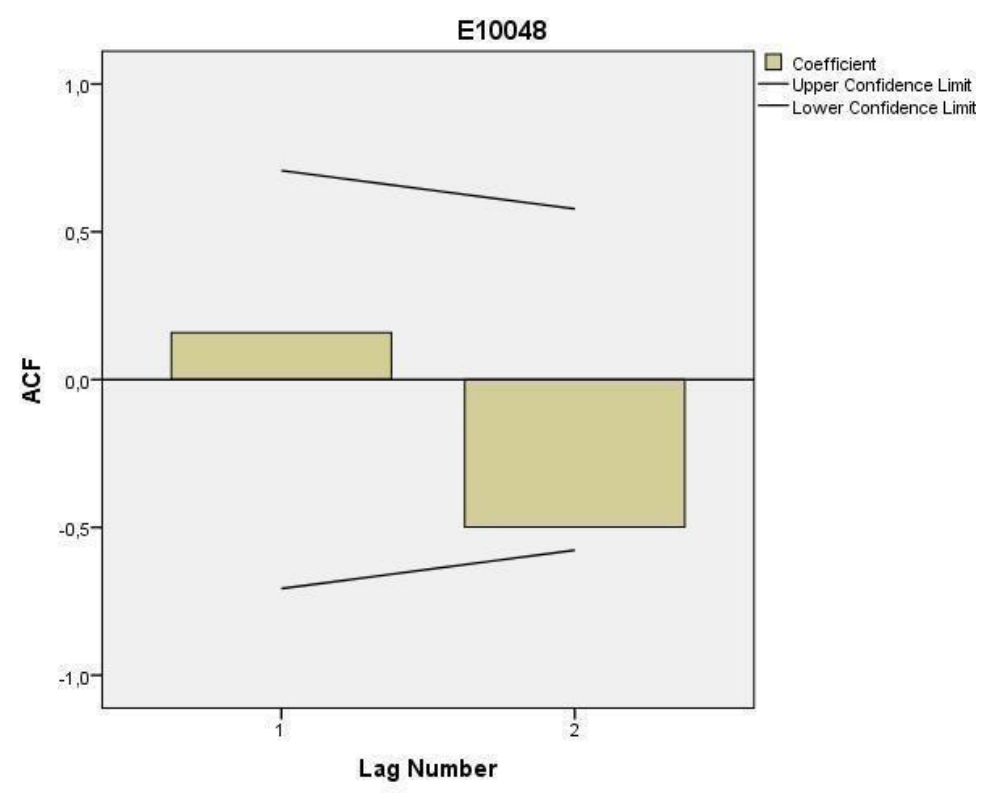

Gambar 1. Plot Nilai Koefisien Autokorelasi Data Asli

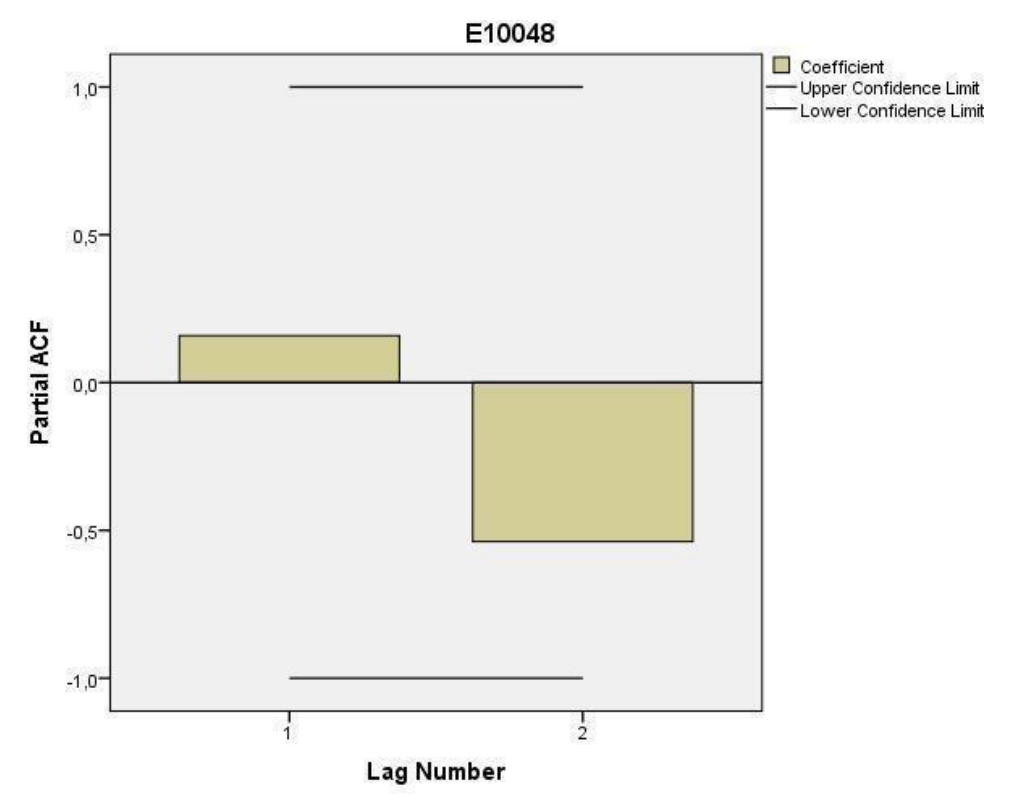

Gambar 2. Plot Koefisien Autokorelasi Parsial

\section{Identifikasi Model}

Untuk menentukan orde proses autoregresif dapat dilihat dari banyaknya nilai koefisien autokorelasi parsial yang berbeda nyata dengan nol. Dari nilai koefisien autokorelasi parsial data asli dapat diketahui bahwa hanya terdapat 1 nilai koefisien autokorelasi parsial yang berbeda nyata dengan nol, yaitu koefisien korelasi lag $1(0,159)$, sehingga orde ( AR)P = 1. Model ARIMA pertama adalah ARIMA $(1,0,0)$.

Urutan proses Autoregressive dan urutan proses Moving Average diperoleh model ARIMA baru, yaitu ARIMA $(1,0,1)$. Sehingga terdapat 3 (tiga) model ARIMA, yaitu: 


\section{Pristiwanto}

doi.org/10.54209/jatilima.v2i1.142

1. $\operatorname{ARIMA}(1,0,0)$

2. $\operatorname{ARIMA}(0,0,1)$

3. $\operatorname{ARIMA}(1,0,1)$

\section{Estimasi Parameter Model}

Tahap selanjutnya setelah model ARIMA diperoleh adalah estimasi, yaitu mencari nilai estimasi yang terbaik atau paling efisien untuk parameter model. Pada tahap ini akan diestimasi parameter yang tidak diketahui yaitu $\mathrm{f}, \mathrm{q}$.

1. Estimasi Parameter Model ARIMA $(1,0,0)$

Tentukan nilai konstanta AR (1), mengikuti nilai konstanta menggunakan program SPSS.

Tabel 3. Parameter Model ARIMA $(1,0,0)$

ARIMA Model Parameters

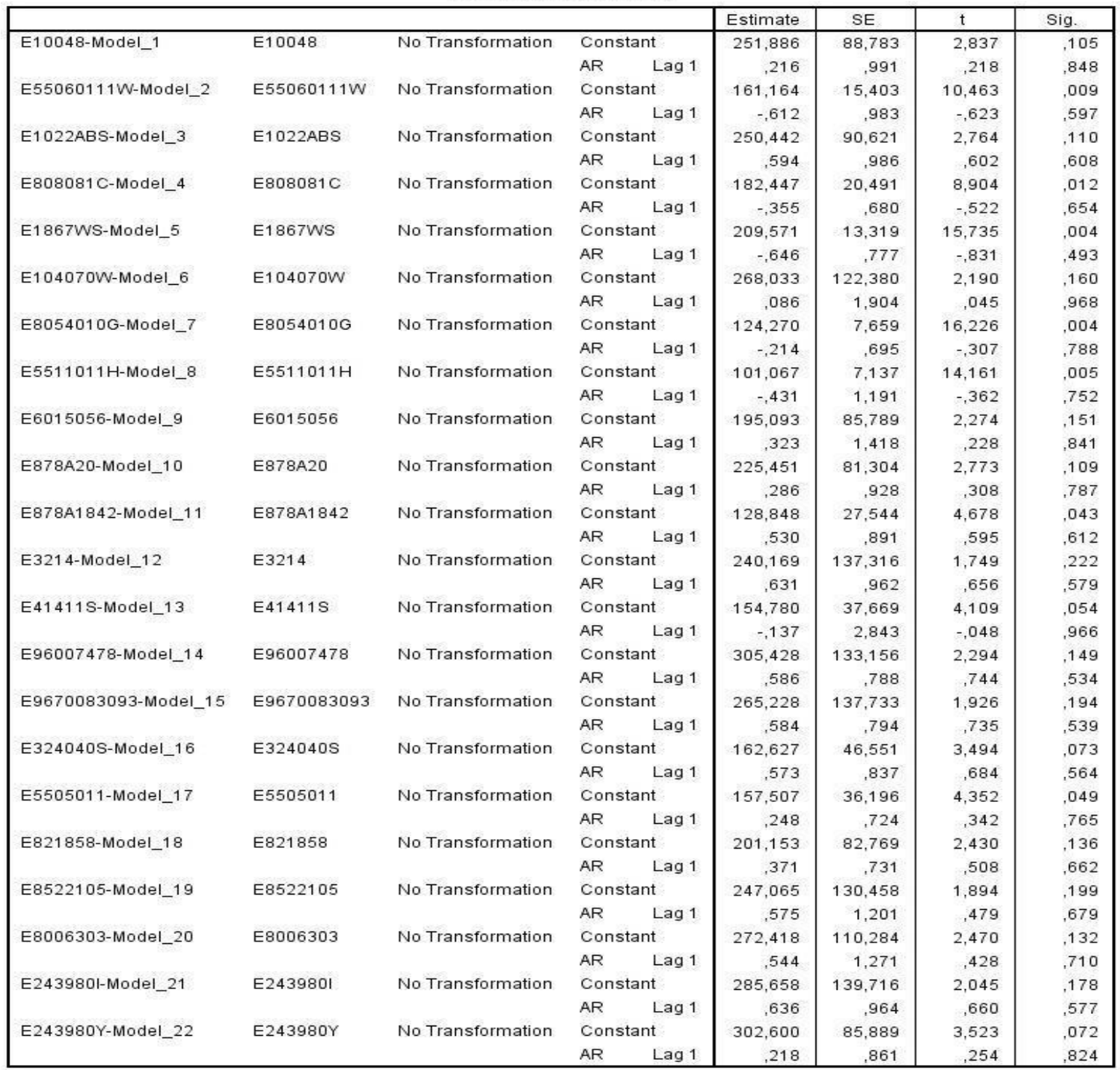

2. Estimasi Parameter ModelARIMA $(0,0,1)$

Tentukan nilai konstanta MA (1), dengan hanya mengikuti nilai konstanta menggunakan program spss. 


\section{Pristiwanto}

doi.org/10.54209/jatilima.v2i1.142

Tabel 4. Parameter Model ARIMA $(0,0,1)$

\begin{tabular}{|c|c|c|c|c|c|c|c|}
\hline & & & & Estimate & SE & $t$ & Sig. \\
\hline \multirow[t]{2}{*}{ E10048-Model_1 } & \multirow[t]{2}{*}{ E10048 } & \multirow[t]{2}{*}{ No Transformation } & Constant & 259,235 & 89,790 & 2,887 & 102 \\
\hline & & & Lag 1 &,- 800 & 1,591 &,- 503 & .665 \\
\hline \multirow[t]{2}{*}{ E55060111W-Model_2 } & \multirow[t]{2}{*}{ E55060111W } & \multirow[t]{2}{*}{ No Transformation } & Constant & 161,483 & 12,476 & 12,943 &, 006 \\
\hline & & & MA $\quad \operatorname{Lag} 1$ & 1,000 & 4122,559 &, 000 & 1,000 \\
\hline \multirow[t]{2}{*}{ E1022ABS-Model_3 } & \multirow[t]{2}{*}{ E1022ABS } & \multirow[t]{2}{*}{ No Transformation } & Constant & 250,787 & 52,663 & 4,762 &, 041 \\
\hline & & & $\operatorname{Lag} 1$ &,- 612 & 1,814 &,- 337 &, 768 \\
\hline \multirow[t]{2}{*}{ E808081C-Model_4 } & \multirow[t]{2}{*}{ E808081C } & \multirow[t]{2}{*}{ No Transformation } & Constant & 181,766 & 11,485 & 15,826 &, 004 \\
\hline & & & $\operatorname{Lag} 1$ & 1,000 & 2044,128 &, 000 & 1,000 \\
\hline \multirow[t]{2}{*}{ E1867WS-Model_5 } & \multirow[t]{2}{*}{ E1867WS } & \multirow[t]{2}{*}{ No Transformation } & Constant & 208,147 & 10,411 & 19,993 &, 002 \\
\hline & & & MA $\quad \operatorname{Lag} 1$ &, 999 & 534,699 &, 002 &, 999 \\
\hline \multirow[t]{2}{*}{ E104070W-Model_6 } & \multirow[t]{2}{*}{ E104070W } & \multirow[t]{2}{*}{ No Transformation } & Constant & 267,850 & 111,590 & 2,400 &, 138 \\
\hline & & & MA $\quad \operatorname{Lag} 1$ &,- 101 & 1,883 &,- 054 & 962 \\
\hline E8054010G-Model_7 & E8054010G & No Transformation & Constant & 124,430 & 4,097 & 30,373 &, 001 \\
\hline & & & MA $\quad \operatorname{Lag} 1$ &, 998 & 416,250 &, 002 & 998 \\
\hline E5511011H-Model_8 & $\mathrm{E} 5511011 \mathrm{H}$ & No Transformation & Constant & 100,233 & 8,221 & 12,192 &, 007 \\
\hline & & & MA $\quad \operatorname{Lag} 1$ &, 998 & 761,961 &, 001 & 999 \\
\hline E6015056-Model_9 & E6015056 & No Transformation & Constant & 194,854 & 62,013 & 3,142 & ,088 \\
\hline & & & MA $\quad \operatorname{Lag} 1$ &,- 244 & 1,388 &,- 176 & .877 \\
\hline E878A20-Model_10 & E878A20 & No Transformation & Constant & 228,931 & 77,785 & 2,943 &, 099 \\
\hline & & & $\operatorname{Lag} 1$ &,- 903 & 3,639 &,- 248 & 827 \\
\hline E878A1842-Model_11 & E878A1842 & No Transformation & Constant & 129,111 & 18,632 & 6,930 &, 020 \\
\hline & & & Lag 1 & -.523 & 1,280 &,- 408 &, 723 \\
\hline E3214-Model_12 & E3214 & No Transformation & Constant & 248,498 & 75,233 & 3,303 &, 081 \\
\hline & & & Lag 1 &,- 999 & 932,255 & -.001 & 999 \\
\hline E41411S-Model_13 & E41411S & No Transformation & Constant & 147,441 & 22,402 & 6,582 &, 022 \\
\hline & & & Lag 1 & 1,000 & 4989,662 &, 000 & 1,000 \\
\hline E96007478-Model_14 & E96007478 & No Transformation & Constant & 319,243 & 84,608 & 3,773 &, 064 \\
\hline & & & Lag 1 &,- 998 & 511,766 &,- 002 & 999 \\
\hline E9670083093-Model_15 & E9670083093 & No Transformation & Constant & 279,518 & 90,494 & 3,089 &, 091 \\
\hline & & & Lag 1 & $-1,000$ & 4804,065 &, 000 & 1,000 \\
\hline E324040S-Model_16 & E324040S & No Transformation & Constant & 165,134 & 27,500 & 6,005 &, 027 \\
\hline & & & MA $\quad$ Lag 1 &,- 999 & 951,013 &,- 001 &, 999 \\
\hline E5505011-Model_17 & E5505011 & No Transformation & Constant & 154,804 & 38,768 & 3,993 &, 057 \\
\hline & & & $\operatorname{Lag} 1$ &,- 998 & 400,636 &,- 002 & ,998 \\
\hline E821858-Model_18 & E821858 & No Transformation & Constant & 202,063 & 74,360 & 2,717 &, 113 \\
\hline & & & MA $\quad \operatorname{Lag} 1$ &,- 999 & 662,216 &,- 002 &, 999 \\
\hline E8522105-Model_19 & E8522105 & No Transformation & Constant & 246,462 & 71,208 & 3,461 &, 074 \\
\hline & & & MA $\quad \operatorname{Lag} 1$ &,- 536 & 1,849 &,- 290 &, 799 \\
\hline E8006303-Model_20 & E8006303 & No Transformation & Constant & 271,703 & 61,276 & 4,434 &, 047 \\
\hline & & & MA $\quad \operatorname{Lag} 1$ &,- 466 & 1,688 &,- 276 & 808 \\
\hline E243980I-Model_21 & E243980I & No Transformation & Constant & 293,744 & 77,433 & 3,794 &, 063 \\
\hline & & & MA $\quad \operatorname{Lag} 1$ &,- 996 & 317,530 &,- 003 & ,998 \\
\hline E243980Y-Model_22 & E243980Y & No Transformation & Constant & 302,262 & 80,391 & 3,760 & .064 \\
\hline & & & MA $\quad \operatorname{Lag} 1$ &,- 245 & 855 & -287 & 801 \\
\hline
\end{tabular}

3. Estimasi Parameter ModelARIMA $(1,0,1)$

Tentukan nilai konstanta MA (1), mengikuti nilai konstanta menggunakan program SPSS. 


\section{Pristiwanto}

doi.org/10.54209/jatilima.v2i1.142

Tabel 5. Parameter Model ARIMA $(1,0,1)$

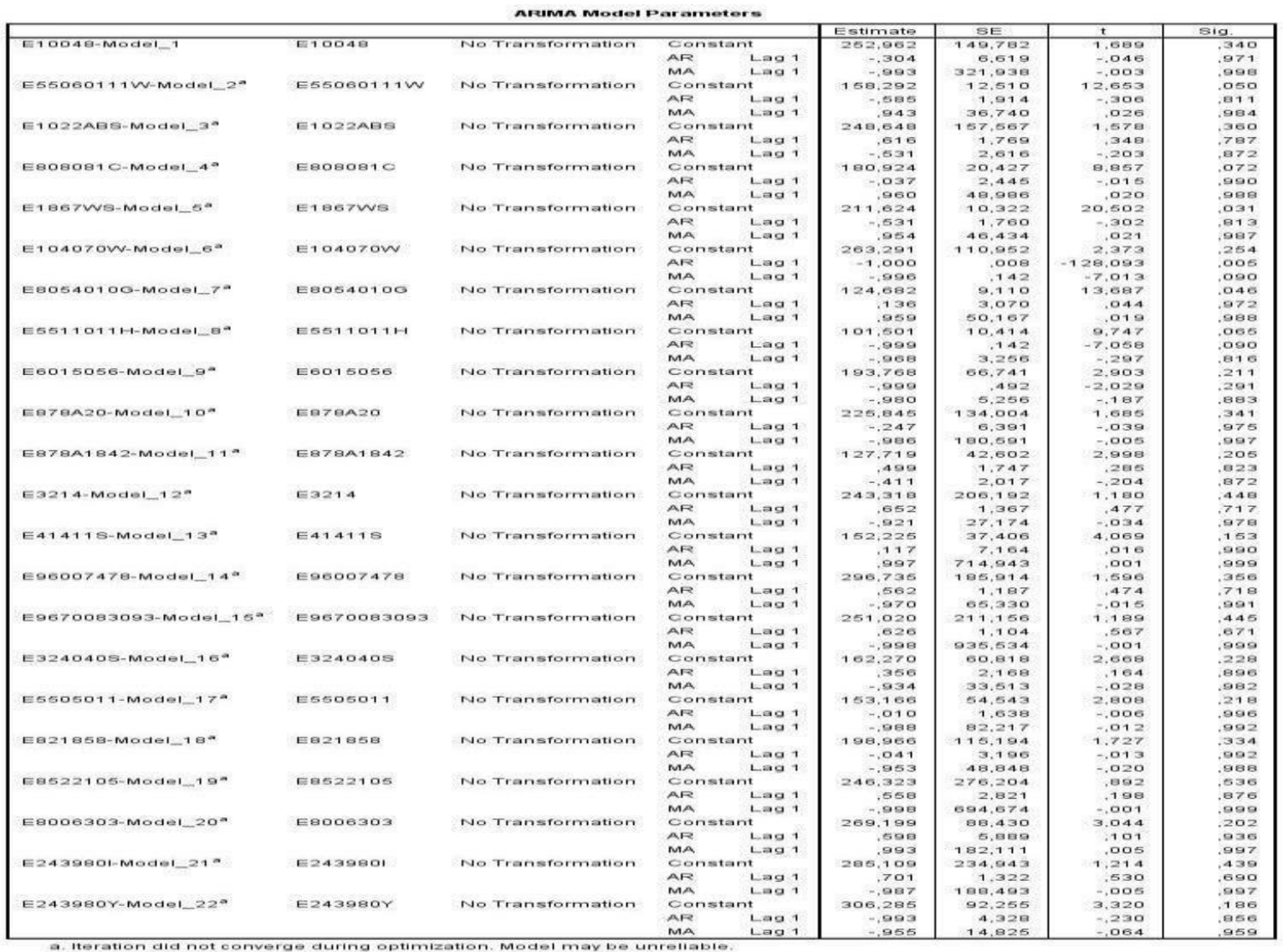

\section{Tahap Peramalan}

Ketiga model yang diperoleh dihitung untuk nilai ramalan tahun 2016. Kemudian dihitung rata-rata persentase error atau MSE. Nilai masing-masing UMK dari ketiga model tersebut dapat dilihat pada tabel berikut ini:

Tabel 6. Nilai MSE Model ARIMA

\begin{tabular}{|l|l|l|}
\hline Model ARIMA & nilai UMK & Ramalan/Prediksi \\
\hline ARIMA (1,0,0) & $17.070=17.1 \%$ & $371($ E9607478) \\
\hline ARIMA $(0,0,1)$ & $15.778=15,8 \%$ & $368($ E9607478) \\
\hline ARIMA (1,0,1) & $22.108=22,1 \%$ & $393(243980 I)$ \\
\hline
\end{tabular}

Nilai MSE terkecil adalah MSE model ARIMA $(0,0,1)$, sehingga model ARIMA $(0,0,1)$ sesuai dengan data jumlah penjualan bingkai foto dengan model ARIMA $(0,0,1)$ dan cocok untuk keperluan Prediksi penjualan bingkai foto tahun 2020. Prediksi penjualan bingkai foto tahun 2020 dengan tingkat kepercayaan 95\%. Interval prediksi dapat dilihat pada tabel berikut: 
Tabel 7. Data Jumlah Penjualan Bingkai Foto Tahun 2020

\begin{tabular}{|l|c|}
\hline \multicolumn{1}{|c|}{$\begin{array}{c}\text { Kode } \\
\text { Bingkai }\end{array}$} & $\begin{array}{c}\text { Tahun } \\
2020\end{array}$ \\
\hline E10048 & 282 \\
\hline E55060111W & 140 \\
\hline E1022ABS & 290 \\
\hline E808081C & 182 \\
\hline E1867WS & 222 \\
\hline E104070W & 285 \\
\hline E8054010G & 121 \\
\hline E5511011H & 88 \\
\hline E6015056 & 219 \\
\hline E878A20 & 242 \\
\hline E878A1842 & 141 \\
\hline E3214 & 305 \\
\hline E414115 & 109 \\
\hline E96007478 & 368 \\
\hline E9670083093 & 337 \\
\hline E324040S & 180 \\
\hline E5505011 & 166 \\
\hline E821858 & 200 \\
\hline E8522105 & 298 \\
\hline E8006303 & 312 \\
\hline E2439801 & 354 \\
\hline E243980Y & 325 \\
\hline
\end{tabular}

Berdasarkan hasil di atas, dapat disimpulkan bahwa prediksi penjualan bingkai foto terbanyak di tahun 2016 adalah bingkai foto dengan kode E96007478 dengan persentase error sebesar $15,8 \%$.

\section{Kesimpulan}

Berdasarkan hasil penelitian yang dilakukan, diperoleh kesimpulan yang sesuai dengan hasil penelitian sebagai berikut: Ektaco Sumber Foto menggunakan data penjualan bulan April 2016 sampai dengan September 2016 untuk mendapatkan prediksi penjualan bingkai foto tahun 2020 menggunakan metode ARIMA. Metode Autoregressive Integrated Moving Average (ARIMA) diterapkan dalam aplikasi SPSS. Hasil prediksi didapatkan setelah menginput data penjualan yang telah tersimpan di excel, kemudian data tersebut di import ke SPSS. Dari hasil implementasi model ARIMA dengan data jumlah penjualan bingkai foto di Ektaco Sumber Foto bulan April 2016 sampai dengan September 2020 dapat disimpulkan bahwa prediksi penjualan bingkai tahun 2020, dengan plot nilai koefisien autokorelasi terhadap identifikasi proses Moving Average $(\mathrm{MA}(\mathrm{q})=1)$, plotkan nilai koefisien autokorelasi parsial untuk mengidentifikasi proses Autoregressive $(A R(p)=1)$, sehingga diperoleh tiga model ARIMA yaitu ARIMA $(1,0,0)$, ARIMA $(0,0,1)$ dan ARIMA $(1,0,1$ ), dengan prediksi penjualan tertinggi kode E96007478 sebanyak 368 bingkai foto menggunakan model ARIMA $(0,0,1)$ dengan MSE nilai 15,778.

\section{Referensi}

[1] A. A. Susanto, "Fotografi adalah Seni: Sanggahan terhadap Analisis Roger Scruton mengenai Keabsahan Nilai Seni dari Sebuah Foto," J. Urban Soc. Arts, vol. 4, no. 1, pp. 49-60, 2017.

[2] W. Wulandari, “Seni Dalam Fotografi Disorientasi," J. Desain, vol. 2, no. 03, pp. 169$182,2015$. 
[3] I. Wahyuni, N. Nafi'iyah, and M. Masruroh, "SISTEM PERAMALAN PENJUALAN PERUMAHAN DI KABUPATEN LAMONGAN DENGAN MENGGUNAKAN METODE REGRESI LINIER BERGANDA," in Seminar Nasional Sistem Informasi (SENASIF), 2019, vol. 3, no. 1, pp. 1969-1973.

[4] D. Pribadi, R. Ramadhan, R. A. Saputra, and J. M. Hudin, "WEB E-COMMERCE DENGAN SISTEM PREDIKSI TRANSAKSI PENJUALAN MENGGUNAKAN METODE K-NEAREST NEIGHBOR,” Swabumi, vol. 6, no. 1, pp. 91-97, 2018.

[5] M. Ferdika and H. Kuswara, "Sistem Informasi Penjualan Berbasis Web Pada PT Era Makmur Cahaya Damai Bekasi," Inf. Syst. Educ. Prof. J. Inf. Syst., vol. 1, no. 2, pp. 175-188, 2017.

[6] T. Pradiani, "Pengaruh sistem pemasaran digital marketing terhadap peningkatan volume penjualan hasil industri rumahan," J. Ilm. Bisnis Dan Ekon. Asia, vol. 11, no. 2, pp. 46-53, 2017.

[7] R. Rahmadayanti, B. Susilo, and D. Puspitaningrum, "Perbandingan Keakuratan Metode Autoregressive Integrated Moving Average (ARIMA) dan Exponential SMOOTHING Pada Peramalan Penjualan Semen di PT. Sinar Abadi," Rekursif J. Inform., vol. 3, no. 1, 2015.

[8] P. L. K. Mustika et al., "Whale strandings in Indonesia, including the first record of a humpback whale (Megaptera novaeangliae) in the archipelago," Raffles Bull. Zool., vol. 57, pp. 199-206, 2009.

[9] A. Nofiyanto, R. A. Nugroho, and D. Kartini, "Peramalan Permintaan Paving Blok dengan Metode ARIMA," Proc. Konf. Nas. Sist. Dan Inform., 2015.

[10] M. B. Pamungkas and A. Wibowo, "Aplikasi Metode Arima Box-Jenkins Untuk Meramalkan Kasus Dbd Di Provinsi Jawa Timur," Indones. J. Public Heal., vol. 13, no. 2, p. 183, 2019.

[11] P. Pristiwanto and A. H. Hasugian, "Steganography Formation by utilizing Enhanced Least Significant Bit Algorithm," J. Info Sains Inform. dan Sains, vol. 11, no. 1, pp. 19-22, 2021.

[12] R. M. Sunyoto, "SISTEM PERAMALAN JUMLAH PENUMPANG KAPAL LAUT DI PELABUHAN TANJUNG PERAK SURABAYA MENGGUNAKAN TRIPLE EKSPONENSIAL SMOOTHING BERBASIS ANDROID."

[13] Arinanda, Komang. "SISTEM PENDUKUNG KEPUTUSAN PENGADAAN ONDERDIL SEPEDA MOTOR BERBASIS WEB." PhD diss., UAJY, 2019.

[14] Agustin, Rima. "Peramalan Data Intermiten Menggunakan Metode Autoregressive Integrated Moving Average dan Neural Network (ARIMA-NN)." PhD diss., Institut Teknologi Sepuluh Nopember, 2018.

[15] Aprilianti, A.E., Ahsan, M.O.H. and Nugraha, D.A., 2019. PREDIKSI HARGA AIR PELANGGAN PERUSAHAAN DAERAH AIR MINUM (PDAM) MENGGUNAKAN METODE ARIMA (AUTOREGRESSIVE INTEGRATED MOVING AVERAGE). Semnas SENASTEK Unikama 2019, 2. 